\title{
Spatial Concentration of Opioid Overdose Deaths in Indianapolis: An Application of the Law of Crime Concentration at Place to a Public Health Epidemic
}

\author{
Jeremy G. Carter, Ph.D. \\ School of Public and Environmental Affairs \\ Indiana University - Purdue University Indianapolis \\ carterjg@iupui.edu \\ George Mohler, Ph.D. \\ Department of Computer and Information Science \\ Indiana University - Purdue University Indianapolis \\ gmohler@iupui.edu \\ Bradley Ray, Ph.D. \\ School of Public and Environmental Affairs \\ Indiana University - Purdue University Indianapolis \\ bradray@iupui.edu
}

\begin{abstract}
The law of crime concentration at place has become a criminological axiom and the foundation for one of the strongest evidence-based policing strategies to date. Using longitudinal data from three sources, emergency medical service calls, death toxicology reports from the Marion county (IN) coroner's office, and police crime data, we provide four unique contributions to this literature. First, this study provides the first spatial concentration estimation of opioid related deaths. Second, our findings support the spatial concentration of opioid deaths and the feasibility of this approach for public health incidents often outside the purview of traditional policing. Third, we find that opioid overdose death hot spots spatially overlap with areas of concentrated violence. Lastly, we apply a recent method, corrected Gini coefficient, to best specify low-N incident concentrations and propose a novel method for improving upon a shortcoming of this approach. Implications for research and interventions are discussed.
\end{abstract}

Keywords: Crime concentration; Opioid overdose concentration; Emergency medical services data; Corrected Gini coefficient; low-N events

This is the author's manuscript of the article published in final edited form as:

Carter, J. G., Mohler, G., \& Ray, B. (2018). Spatial concentration of opioid overdose deaths in Indianapolis: An application of the law of crime concentration at place to a public health epidemic. Journal of Contemporary Criminal Justice. DOI: 10.1177/1043986218803527 
Rising rates of opioid use in the United States over the past decade have contributed to the recent opioid epidemic (Manchikanti et al., 2012; Nelson et al., 2015). While there have been reductions in prescribing rates in recent years, rates of opioid prescribing remain three times higher than in 1999 (Guy et al., 2017). The result of this recent opioid epidemic has been dramatic increases in deaths due to drug poisoning which quadrupled from 1998 to 2008 (Centers for Disease Control and Prevention (CDC), 2011). Over a similar time period, hospitalizations for prescription opioids increased by 65 percent (Coben et al., 2010) and accounted for the vast majority (73.8\%) of all prescription drug deaths (CDC, 2011) and 40 percent of all drug poisoning deaths (Warner et al., 2011). While the opioid epidemic was initially fueled in part by revised guidelines for the management of chronic pain (Wilson et al., 1997), which resulted in massive increases in opioid prescribing, more recently deaths have shifted from prescription to illicit opioids. In 2016 nearly half (45.9\%) of opioid-related deaths contained fentanyl (Jones et al., 2018), an opioid that is 50 to 100 times more potent than morphine (Algren et al., 2013)

Research demonstrates the bulk of urban crime concentrates within small proportions of micro-places, thus enabling police to identify criminogenic places for intervention (Weisburd, 2015). Recently this approach has been applied to crime-specific problems to enable tailored interventions. Moreover, it has become increasingly evident that persons entering the criminal justice system, as well as victims of crime, suffer from co-occurring disorders related to mental health and substance abuse; a concern that is exacerbated within criminogenic places (White \& Weisburd, 2017). As will be discussed in detail to follow, an empirical estimation of crime concentration to public health concerns holds significant promise to improve policing, meet muchneeded clinician and service demands, and generate positive outcomes for urban communities. The present study leverages multiple data sources to quantify the spatial concentration of opioid 
overdose deaths, the extent to which these opioid hot spots overlap with other crime and drug hot spots, and provides guidance for future crime concentration research and improved social intervention.

\section{Crime Concentration at Place}

For the past 30 years criminologists have focused on the importance of place in understanding crime occurrence and effective interventions to generate crime control benefits. Indeed, there has been voluminous scholarly attention to the empirical establishment of crime and place that has led to a phenomenon Weisburd (2015) coined as the "law of concentration at places" (also see Weisburd, Groff, \& Yang, 2012). This law asserts "that for a defined measure of crime at a specific micro-geographic unit, the concentration of crime will fall within a narrow bandwidth of percentages for a defined cumulative proportion of crime” (Weisburd, 2015, p. 133). Leveraging crime data from cities of various size, Weisburd (2015) established these bandwidths, which are cumulative proportions of crime, as constricted proportions of a geography that generate the bulk of urban crime. Specifically, he found that $50 \%$ of crime concentrates within a bandwidth of roughly four percent of city geography, with $25 \%$ of crime concentration within a bandwidth of approximately one and a half percent.

A growing body of evidence reaffirms crime and place research to be effectively translated into effective social interventions. Recent research suggests crime concentration is stable over time (Andresen \& Malleson, 2011; Braga et al., 2010; Weisburd et al., 2004; Wheeler et al., 2016), thereby increasing the likelihood that interventions focused on criminogenic places may yield crime control benefits. A robust evidence-base on hot spots policing, wherein police activities are focused within ad hoc micro-places that account for high proportions of crime, demonstrates place- 
based policing can generate crime reductions in the focus area as well as diffuse to nearby areas (Braga et al., 2014). Place-based interventions such as hot spots policing do not simply displace crime. Research indicates that overall crime does not spatially displace (Braga et al., 2014; Weisburd et al., 2006) or it does so at a lower rate than the treatment effect resulting in a net positive intervention (Guerette \& Bowers, 2009; Ratcliffe et al., 2011). Such effects are echoed in a recent report by the National Academies of Sciences, Engineering, and Medicine (2018) that further supports proactive policing and crime control efforts focused on high-crime places as effective crime reduction approaches.

Several recent crime and place studies have tested the reliability of Weisburd's law of crime concentration, largely finding support for the identified bandwidths. Other crime and place studies have sought to deepen our understanding of the crime and place phenomenon by exploring the spatial concentration of crime-specific events or other social problems to which police and public services must respond. For example, Wheeler (2017) examined the concentration of 311 calls for service at street segments and Mair et al. (2013) assessed the spatial concentration of vendors who sold alcohol in neighborhoods, both looking at the relationship with crime to inform potential policing interventions. The present study adopts the latter form in estimating the spatial concentration of opioid overdose deaths. Though not specifically testing Weisburd's law of crime concentration, the law does provide a benchmark for establishing crime concentration at levels that are likely to promote effective interventions. Put simply, if observed spatial concentrations are similar to, or more highly concentrated than, Weisburd's (2015) established bandwidths, this lends credence to both the theoretical understanding and policy relevance of leveraging spatial analyses to combat social problems. As such, we leverage Weisburd's concentration bandwidths as an 
empirical gauge and discuss the observed concentration levels of opioid overdose deaths in context of the law's bandwidths of crime.

\section{Occurrence of Crime at Place}

Sherman et al. (1989) noted even the most dangerous neighborhoods are relatively safe places, thus asserting a focal need on micro-places within neighborhoods to understand social problems. Community theories of crime contend that social and structural challenges of neighborhoods are most concentrated in micro-places, thereby generating crime concentration. Indeed, these challenging community characteristics have been found to be most severe within micro-places of crime concentration (Weisburd, et al., 2012b; Weisburd et al., 2014). Environmental and crime pattern theories suggest motivated offenders interpret and respond to environmental cues that make offending more or less suitable. Such cues, or environmental characteristics, may be concentrated within micro-places of larger areas and help explain large proportions of crimes that occur in small proportions of places (Brantingham, 2016; Brantingham \& Brantingham, 1981; Weisburd et al., 1993).

Crime concentration studies have largely been evidenced with general crime, disorder, or calls for service measures. This approach is consistent with community and disorder theories of crime that support the general occurrence of crime in geographies (Taylor, 2015) that result from poor community structures (Sampson, Raudenbush, \& Earls, 1997; Weisburd et al., 2012a) and a lack of social controls (Skogan, 1990; Wilson \& Kelling, 1982). A general view of crime concentration also makes logical sense from an intervention perspective, as police are responsible for all crimes, disorder, and calls for service; thus the extent to which these problems concentrate at places is informative for police response. However, there is a growing body of research that 
seeks to further refine our understanding of crime concentration through crime-specific estimates (Andresen, Curman \& Linning, 2017; Haberman, 2017; Schnell, Braga \& Piza, 2017). These perspectives embrace environmental theories of concentration within geographies (Clarke \& Cornish, 1985; Wortley \& Mazerolle, 2008) that derive from opportunities for crime in space and time (Cohen \& Felson, 1979) and offenders' assessments of crime execution derived from environmental and social factors (Brantingham \& Brantingham, 1993).

From an environmental and crime pattern perspective, the specific or general concentration of crime is dependent on environmental cues. Brantingham (2016) acutely articulates this issue in his examination of crime diversity and spatial concentration. On the one hand, if environmental cues are general in nature, then motivated offenders will engage in criminality across various crime types - leading to a broader array of crime types within hot spots. Conversely, if environmental cues within a micro-place are specific to certain crime types then only these crime types facilitated by the environmental cues should concentrate (i.e., crime-specific concentration). Additionally, offenders may adhere to crime-specific scripts informed by routine activities within space and time, and such scripts may help to explain the observed variations of crime concentration in microplaces (Olaghere \& Lum, 2018). However, environmental cues are not restricted to the built or physical environment. Offending cues may be exhibited through a convergence of physical and social features, namely the structural community characteristics that are often the focus of general explanations of crime and place (Baudains, Braithwaite, \& Johnson, 2013; Braga \& Clarke, 2014; Johnson \& Summers, 2015). Given the absence of spatial studies focused on opioid drug use, it is unclear if the spatial concentration of opioid-related deaths may be explained by specific or general environmental cues. We explore this inquiry in the present study through a spatial overlap of opioid overdose death concentrations with other crime hot spots. Previous research suggests drug use 
offending and other crime types will occur in similar micro-places, largely as an artifact of the societal challenges exhibited within high-crime micro-places.

Weisburd (2018) calls for criminologists to recognize that hot spots of crime are also hot spots of social inequalities and challenges. In their study of Tel Aviv hot spots, Weisburd et al. (2017) found residents of hot spots demonstrated higher levels of divorce and unemployment, were less likely to own their homes, and earned less money at work when compared to residents of lowcrime places. Residents of hot spots have also been found to exhibit common correlates attributed to substance abuse problems, such as mental illness, physical ailments, and legal substance use (Compton et al., 2005; Weisburd et al., 2012b). Weisburd, Lawton, and Ready (2012) surveyed residents living in hot or cold spot street segments in Baltimore, Maryland and concluded that residents living in hot spots were significantly more likely to be diagnosed with depression and less likely to seek professional treatment for their condition, had higher levels of physical health problems such as arthritis, asthma, high blood pressure, and diabetes, were more likely to suffer from symptoms of post-traumatic stress disorder, and were twice as likely to have an illegal substance abuse problem. Given the presence of such social challenges within hot spots, and their relationship to substance use, research supports a logical assumption that drug-related activity will concentrate within micro-places akin to the concentration of general crime and disorder.

Weisburd and Green (1995) observed that all repeat narcotics sales arrests, drug emergency calls for service, and narcotic tip-line information in New Jersey could be mapped to five percent of all city street intersections. Using both emergency medical service (EMS) and police calls for service data in Seattle for the year 2004, Hibdon and Groff (2014) examined the law of crime concentration at place specific to drug-related activities. Their analyses demonstrate that overall 50 percent of drug activity concentrated within 1.11 percent of street segments, with 100 percent 
of drug activity within 11.11 percent. Hibdon, Telep, and Groff (2017) further extended this inquiry using both EMS and police data in Seattle from 2009-2014 to test the stability of drug activity concentration. Results of their spatial concentrations mirror those of their previous work. Combined EMS and police drug activity concentrations during this temporal period for 25 percent of all drug activity ranged from .19-.25 percent, 50 percent of drug activity between 1.18-1.39 percent, and 100 percent of drug activity within 15.59-16.81 percent of street segments. However, their group-based trajectory analysis of stability, operationalized as a collection of street segments of similar drug call volumes, exhibited variations of concentration over time - thus lending further support the importance of considering micro-level crime-specific analyses of crime concentration.

Moreover, Hibdon et al. (2017) suggest this temporal instability may be the result of underlying mechanisms that may influence drug activity, such as enforcement priorities of police and citizens as well as the relationship between drugs and other crime types that may receive police attention and have a subsequent scatter effect on drug dealers and users. Related to this point, Lum (2008) examined the spatial relationship of drug activity and violence. Using Seattle police data from 1999-2002 a corollary relationship was observed among levels of drugs and violence within census tracts. However, spatial dependence tests revealed not all high drug crime areas also experienced high levels of violence, and vice versa. Her findings suggest, from a routine activities and opportunities perspective, that a refined understanding of high-drug activity places would be informative for effective police intervention. Taken together, there exists a strong body of evidence that the concentration of crime at places can result in an improved understanding of crime and tangible crime prevention benefits. Crime and place research has progressed from a concept to a criminological axiom, with next steps focused on an application to specific incidents and a broader set of social challenges. Drug activity has been one such specific focus that can be further refined 
to address emerging public health issues. To this end, the present study examines the spatial concentration of opioid overdose deaths in Indianapolis.

\section{Study Site and Context of Opioid Epidemic}

The state of Indiana has been significantly impacted by the opioid epidemic. According to the Substance Abuse and Mental Health Services Administration and Center for Behavioral Health Statistics and Quality (2017) Treatment Admissions Data on Indiana, from 2004 through 2015 the frequency of prescription drug and heroin reported as drug of choice has increased 413 percent and 155 percent respectively. Like much of the United States there have also been dramatic increases in deaths associated with opioids. Since 2008 opioid-related death rates have risen from 4.5 to 11.7 per 100,000 in 2016 (State of Indiana, 2018). Well above the national average, drug poisoning is the leading cause of death from injury in Indiana (Warner et al., 2011). In 2015 Indiana ranked $13^{\text {th }}$ in drug-related deaths and $19^{\text {th }}$ in opioid-involved deaths (Centers for Disease Control and Prevention, 2016). However, it is important to note that Indiana also ranks $5^{\text {th }}$ in the proportion of unspecified drug overdose deaths (Casteel, 2018). For example, it may be known that the cause of death was due to drug overdose, but the specific substance, opioids in this case, is not indicated as a contributing cause - a practice that has been attributed to the lack of a state medical director (Warner et al., 2013). Therefore, we know that the true toll of the opioid epidemic is worse than is generally reported.

Indianapolis has been home to a large majority of the state's opioid deaths with recent evidence echoing national patterns in finding increases in heroin- and fentanyl-related overdose deaths (Phalen et al., 2018). The arrival of fentanyl - a synthetic opioid 50 times more potent than heroin (National Center for Injury Prevention and Control 2016) - within the U.S. illicit drug 
market has further increased the risk of fatal opioid overdose. Despite fentanyl's prevalence in the illicit drug market, heroin has remained the focus of overdose fatality assessments. This is because the International Classification of Diseases (ICD), the standard diagnostic tool used by the Centers for Disease Control and Prevention (CDC) to examine mortality trends, codes fentanyl and many other loosely related drugs together under the same umbrella category "synthetic opioids", with no unique diagnostic code for fentanyl specifically (Wysowski, 2007; Fernandez et al., 2006; Ossiander, 2014). From 2014 to 2015 heroin death rates increased by 20.6 percent, yet deaths from synthetic opioids increased by 72.2 percent. The CDC notes this increase is most likely attributable to illicitly manufactured fentanyl; however, ICD codes are not able to assess trends by a specific substance. This is problematic, as policy and program responses to the opioid epidemic require accurate information regarding the drugs driving overdose trends to maximize their effectiveness.

\section{Data}

This study relies on three sources of data. The first source of data capture the precise location of fatal drug overdose deaths. Given limitations of ICD codes and concerns of undercounting, researchers from Indiana University have an ongoing collaboration with the Marion County (Indiana) Coroner's Office (MCCO) to collect toxicology data on all drug overdose death cases since 2010. The research team maintain a database with information from death certificates and toxicology reports on all drug overdose fatalities, including the location of the overdose (the location at which EMS personnel responded). The presence of opioids and other substances are captured from toxicology reports. Opioids we were able to consistently code for during this time period included fentanyl and six types of monoacetylmorphine (heroin), morphine, codeine, oxycodone, hydrocodone, oxymorphone, and hydromorphone. 
It should be noted that one of the limitations of using toxicology data is the inability to accurately identify the presence of morphine and codeine. Specifically, because some illicit manufactured opioids, such as heroin, undergo a rapid transformation into natural opioids morphine and codeine (Avella, Katz, \& Lehrer, 2007), we follow previous work looking at polydrug interactions (Harruff, Couper, \& Banta-Green, 2015) and did not include morphine or codeine though did include these substances in our overall detection of opioids. Therefore, using the toxicology results we coded cases into three categories: any opioid-related deaths, prescription opioid-related deaths, and illicit opioid-related deaths. Detection of oxycodone, hydrocodone, oxymorphone, or hydromorphone were used to for prescription opioids while detection of heroin or fentanyl were used to for illicit opioids. Importantly, these categories are not mutually exclusive as cases can contain both prescription and illicit opioids. The detection of any of opioid substances was used for the 'any opioid-related death' measure.

The second source of data come from emergency medical calls for service (EMS) and were provided electronically by the Indianapolis Emergency Medical Services department for years 2012-2016. The current study is concerned specifically with drug overdose calls for service. Such overdose calls are inclusive of all drug types (illicit and prescribed) as well as both fatal and nonfatal outcomes. One limitation of these data for the present study is the inability to parse out opioidspecific overdose calls for service from other drug types. However, we believe this inclusive measure of drug overdose calls best captures both the demand on EMS services related to drugs and the drug-using environment where these calls originate. Another limitation concerns the double counting of cases where EMS responded to an overdose and there was a corresponding fatality. Recent research suggests this is unlikely as EMS do not often respond to events where an 
individual has already died and there are few instances in which an overdose results in a death where EMS are called to respond (Ray et al. 2018).

Lastly, crime data were provided electronically from the Indianapolis Metropolitan Police Department (IMPD) for years 2012-2016. Both crime and drug overdose data included date and time stamp as well as state-plane coordinates from a composite address locator that were converted to WGS84 coordinates. The address locator first attempts to geocode incidents to parcels and then geocodes any unmatched incidents to street centerlines using an offset distance of 40 feet. The use of dual reference data tables (parcel and street centerlines) helps to maximize the geocoding hit rate (Braga et al., 2010). Over 99\% of incidents for each crime and drug overdose type geocoded successfully, exceeding the $85 \%$ minimum geocoding rate suggested by Ratcliffe (2004) and thereby including virtually all incidents in the current analyses.

\section{Analytic Strategy and Results}

\section{Event Concentration of Opioid Overdoses and Crime}

We first analyze the spatial concentration of opioid overdose deaths compared to other crime event categories in Indianapolis, Indiana. We divide the city into a grid of equally sized 500m x 500m cells (we conduct additional analyses for 1000m cells). For a given event category, we calculate the number of events falling in each cell. We then rank the cells by the event counts, calculating the percentage of total events falling in the top 1 percent, 2.5 percent and 5 percent of cells (Mohler, Short, \& Brantingham, 2017). For example, we find that 17 percent of opioid related deaths fall in the top one percent of 500m x 500m cells. Similar analyses are used to demonstrate the concentration of crime on street segments (Weisburd, 2015; Hipp \& Kim, 2017) as well as 
spatiotemporal patterns of crime (Garnier, Caplan \& Kennedy, 2018). We present the results of this analysis in Table 1.

In general, the concentration of crime increases (meaning more crime in a smaller area) as the cell size and percentage area flagged decrease (see Bernasco \& Steenbeek, 2017; Hipp \& Kim, 2017; Mohler et al., 2017). Consistent with previous research using EMS drug data (Hibdon \& Groff, 2014; Hibdon et al., 2017) and drug-specific crime data (Weisburd \& Green, 1995), drug overdoses as recorded by EMS calls for service and each of the three opioid death types (any, illicit, and prescription) all exhibit high concentrations across the varying grid cell sizes and flagged area percentages. Violent crime (robbery and assault) also concentrates in micro-places in Indianapolis, followed by lower levels of concentration for property crime (burglary and motor vehicle theft). As highlighted in Table 1, focusing on the five percent of places and 50 percent of crime bandwidth identified by Weisburd (2015), any opioid death (53.5\%), any illicit opioid death (57.5\%), and any prescription opioid death (64.8\%) all exceed this concentration bandwidth at the 500m grid cell level - followed closely by drug overdose calls (49.0\%). These findings lend initial evidence to the applicability of spatial concentration methods to non-traditional crime measures with salient social intervention and public health implications.

\section{[ Insert Table 1: Concentration by Incident Type, Cell Size, and Percent of Area Flagged approximately here ]}

\section{Corrected Gini Coefficient for Measuring Opioid Overdose Concentration}

The concentration levels for opioid related deaths in Table 1 should be interpreted with caution due to the low event counts (less than 1000). As Bernasco and Steenbeek illustrate, when the number of observation cells $\mathrm{N}$ out number events $\mathrm{C}$, concentration will appear artificially high. For example, in the extreme case where there is only one event, $\mathrm{C}=1$, then 100 percent of events 
are captured in one out of N cells. Bernasco and Steenbeek (2017) suggest using an adjusted Gini coefficient (or Gini index), G', in this situation. Let the Gini coefficient G be the area between the Lorenz curve (the curve that plots crime concentration versus percent area flagged) and the line of equality (which corresponds to random distribution of crime). Then the corrected Gini coefficient G' is the area between the Lorenz curve and the line of maximal equality, which has slope N/C. In this case, the Lorenz curve is compared to the line representing the concentration of crime if it were maximally dispersed (a single event in each cell up to C cells). Adhering to Bernasco and Steenbeek (2017), G’ is calculated as:

$$
G^{\prime}=\max \left(\frac{1}{c}, \frac{1}{n}\right)\left(2 \sum_{\{i=1\}}^{n} i y_{i}-n-1\right)-\max \left(\frac{n}{c}, 1\right)+1
$$

In Table 2, we present the corrected Gini coefficient for opioid related deaths versus other crime categories. The crime categories are similarly ranked in terms of concentration compared to Table 1, again these specific levels are highlighted in Table 2. For 1000m grid cells the Gini coefficient for opioid related deaths is higher than that of burglary, motor vehicle theft, and assault, but it is now lower than robbery. For 500m grid cells, opioid related deaths has the least concentration of all event categories.

\section{[ Insert Table 2: Corrected Gini Coefficients by Incident Type and Cell Size approximately here ]}

Here we point out one flaw of the adjusted Gini coefficient, namely that it over corrects and under-estimates crime concentration at low event counts. To illustrate, we present the following scenario. Assume crime is stationary in time and that the rate of crime in each grid cell is a constant (but possibly different across grid cells). If we observe this process for a long period of time, we may use the empirical, un-adjusted Gini index estimator given by G (Bernasco \& 
Steenbeek, 2017). However, if we observe for a short period of time then many cells will have zero counts leading to a bias of G towards 1 . The problem with the adjusted Gini index G' is that it is biased towards zero for low event counts. To show this we assume the Poisson rate of events in each of $\mathrm{N}=1000$ cells is an iid Gamma random variable with shape .8 and scale 7.3 (overall the model is a Poisson-gamma mixture). We then simulate 40,000 data sets where in each simulation the Poisson process across the grid cells is simulated for $\mathrm{t}$ time units, where $\mathrm{t}$ is a random number between 0 and 4 (thus yielding data sets of different sizes all with the same true Gini index). In Figure 1, we plot G (red) and G' (blue) as a function of the number of events in the data set (with $\mathrm{N}=1000$ cells fixed). At low event counts G' underestimates concentration, at intermediate counts it converges to $\mathrm{G}$ and thus overestimates concentration, and for large counts both Gini coefficients converge.

\section{[ Insert Figure 1: Poisson-Gamma Simulation of Gini and Corrected Gini Coefficients approximately here ]}

\section{Opioid Overdose Concentration in Leading Indicator Hot Spots}

To address the low-N Gini coefficient issue, we propose using leading indicator hot spots (Cohen et al., 2007; Mohler, 2014) as a proxy for measuring the concentration of opioid related deaths. This approach has the added benefit of highlighting correlation between crime and opioid related hot spots. We proceed by defining the hot spots for each event type as in Table 1, but now we measure the concentration of opioid related deaths in the other incident type hot spots. We present the analysis in Table 3. We now see that 49 percent of opioid related deaths fall in the top five percent of drug overdose hot spots and 48.5 percent of robbery hot spots (the same as the percent of robberies falling in robbery hot spots). In Figure 2 we plot density maps of all of the 
event categories to illustrate these correlations presented in Table 3. In addition to drug overdoses and robbery, opioid related deaths concentrate in assault (40\%) hot spots, and to a lesser degree in property crime hot spots (33-34\% in 5\% of places). In summary taking into account these three separate measures, opioid related deaths concentrate to an equal or greater degree compared to crime events. Furthermore, opioid death hot spots significantly overlap with violent crime hot spots - echoing previous research by Lum (2008) who found spatial overlap between drug and violent hot spots in Seattle.

[ Insert Table 3: Opioid Death Concentration in Leading Indicator Hot Spots approximately here ]

[ Insert Figure 2: Density Maps of Opioid Death Concentrations within Other Incident Hot Spots approximately here ]

\section{Discussion and Conclusions}

The present study reports, to our knowledge, the first spatial concentrations of opioidrelated deaths and makes four unique contributions to the crime and place evidence base. First, we estimate the spatial concentration of opioid-related overdose deaths and contextualize these concentration levels relative to Weisburd's (2015) anticipated bandwidths of crime concentration. Relative to the law's bandwidths, opioid-related overdose deaths in Indianapolis more highly concentrate as compared to other crime types. Five percent of places (using 500m grid cells) account for 53.5 percent of any opioid death, 57.5 percent of any illicit opioid death, 64.8 percent of any prescription opioid death, and 49.0 percent of EMS drug overdose calls. Though these observed concentration levels are higher than general crime concentration estimates noted by Weisburd (2015), they are consistent with highly concentrated levels of police and EMS calls for service related to drugs (Hibdon \& Groff, 2014; Hibdon et al., 2017; Lum, 2008). Other crime 
types, such as robbery and assault, concentrate at levels consistent with expected observations. Second, our findings lend support to the applicability of leveraging spatial concentration methods to develop social interventions, akin to hot spots policing, to combat public health incidents often outside the purview of traditional policing. Third, we find that opioid overdose death hot spots spatially overlap with areas of concentrated violence. Lastly, we apply a recent method, corrected Gini coefficient, to best specify low-N incident concentrations and propose a novel method for improving upon a shortcoming of this approach by using leading indicator hot spots as a proxy for measuring concentration. Beyond advancing the academic understanding of opioid related deaths and crime concentration, the findings have implications for directed social interventions.

From an environmental and crime pattern perspective, our findings suggest two offenderenvironment interactions may be at play. First, opioid-related drug activity overlaps with other crime in Indianapolis - specifically hot spots of general drug use and violent crime. This overlap suggests these micro-places exhibit general environmental cues conducive to offending, and such locations will subsequently experience higher rates of diverse crime types (Brantingham, 2016). These general environmental cues may give rise to macro-routines of activities that reflect general criminal behavior in a given location (Lum, 2008). Put simply, these locations are likely to be viewed as generally suitable for criminal offending due to their lack of place managers or guardians, routines of known offenders (or drug users in this case), as well as other built and socioenvironmental factors (Madensen \& Eck, 2013). These macro-routines at places give way to perspectives on offender foraging (Brantingham \& Tita, 2008; Johnson \& Bowers, 2004; Johnson, Summers \& Pease, 2009) wherein offenders seek to maximize offending opportunities while minimizing risk, and do so by identifying optimal locations to offend (Johnson, 2014). These routine and rationale offending processes lead to concentrations of crime events in space and time. 
Second, opioid-drug activity in Indianapolis is highly concentrated in micro-places. It is possible that such micro-places foster specific environmental cues that facilitate opioid-related drug activity. Anecdotally, through conversations between the research team, the police, and social service providers, such cues may take the form of homeless shelters, missions, and areas with high degrees of vacant housing. These environmental characteristics, again anecdotally, have been a focus of police and social service interventions for opioid use in Indianapolis. For example, drug dealers may target populations of homeless persons and sell opioids around shelters and missions, as well as vacant homes where homeless persons seek shelter and provide space to engage in drug use. These are likely the same location in which persons use drugs immediately upon purchase. This sequence of events likely mirrors micro-routines of activities that are more restricted in space and time (Olaghere \& Lum, 2018) and lead to higher levels of specific crime concentrations. Micro-routines can be described as crime-specific activities nested within macro-routines of offending. For example, drug dealers may identify suitable locations to target drug users then travel to these locations and hang around (macro-routine) and subsequently engage in micro-routine activities to offend, such as position themselves by a homeless shelter at a known opening or closing time (Olaghere \& Lum, 2018). Micro-routines may be promising for intervention development as they involve offenders' decisions to follow scripts (Chiu, Leclerc \& Townsley, 2011) that can be leveraged by police to identify prevention points (Cornish \& Clarke, 2002).

Generally, police presence within hot spots communicates to offenders an increased perception of being apprehended, and thus generates crime deterrence effects (Ratcliffe et al., 2011). Specific to drug hot spots, increased police activity in the form of crackdowns have been shown to significantly reduce drug offending. Weisburd and Green (1995) found increased patrols and arrests by narcotics and patrol officers in Jew Jersey drug hot spots reduced during crackdowns 
periods. Lawton, Taylor, and Luongo (2005) concluded similar results in their evaluation of Operation Safe Streets in Philadelphia. Though they caution their findings due to observations of spatial displacement, net drug crime reductions in the treatment areas were positive. Weisburd et al. (2006) provide further support that drug crimes do not displace and crackdowns in drug areas are likely to yield diffusion of benefits effects. A diffusion of benefits could be expected as increased police activity in drug hot spots can directly impact drug offenders and subsequent drug crimes, but also indirectly impact other crimes. As is the case in Indianapolis, and other cities as noted previously, drug hot spots overlap with other crime hot spots. Thus, increased police activity focused on drug incidents may also translate into deterrent effects of other crimes (Weisburd \& Mazerolle, 2000).

These studies each speak to the importance of post-crackdown follow-up efforts by police in the form of problem-oriented policing strategies, or what Braga and Weisburd (2006) refer to as "enforcement problem-oriented policing", to generate more long-term drug crime reductions. A problem-oriented focus in drug hot spots is further supported by the recognition that this strategy is perhaps the most promising policing approach in all hot spot types (Braga et al., 2014; Weisburd \& Telep, 2014). This is especially true given the likely occurrence of micro-routines within highconcentration opioid places. Police and social service providers should partner to best identify activity scripts for both opioid offender (sellers) and drug users to trailer interventions following a problem-oriented framework. Interventions could focus on crime prevention, but also improved service delivery and diversion.

It should be noted that a recommendation for increased police activity and crackdowns in drug hot spots to reduce opioid overdose deaths operates under the assumption that overdose deaths and drug-related activities, such as dealing and purchasing illicit drugs, are positively 
correlated. Unfortunately, data on drug dealing activity was not available during the temporal study period. In 2014 IMPD changed their records management system and drug dealing call types changed in this process (other data fields used in these analyses remained consistent and were subjected to reliability checks) and resulted in a lack of valid data to explore the spatial overlap between drug dealing and opioid related deaths. Future spatial studies of opioid deaths should attempt to shed light on this possible relationship.

Spatial concentrations of opioid related deaths can also inform innovative police-social service partnerships. For example, police departments across the country are experimenting with patrol units dedicated to the response of mental health and drug-related calls for service (Reuland, Draper \& Norton, 2010). These co-response teams sometimes offer a pre-booking diversion response or assist in clinical follow-up after an overdose event has occurred (Shapiro et al., 2014). This movement also coincides with an emerging call from scholars for police to focus on social harm as opposed to just crime (Mohler, Carter, Raje, 2018; Ratcliffe, 2015; Sherman, Neyroud \& Neyroud, 2016). A primary catalyst for this approach is the realization that many offenders and victims of crime suffer from co-occurring disorders related to mental health and substance abuse, and that the presence of co-occurring disorders makes service delivery to these individuals even more challenging (White \& Weisburd, 2017). These patrol units are typically comprised of a sworn police officer, an EMS responder, and some form of social clinician or service provider. White and Weisburd (2017) report findings from one such pilot project in Baltimore, Maryland and suggest initial outcomes included improved service delivery for mental health and substance abuse while simultaneously improving police-community relationships.

This latter finding is noteworthy as crime and place research has reinforced the importance of collective efficacy in high crime places. If service-delivery patrols can yield improved police- 
community relationships, these relationships can be coupled with perceived improvements of service-delivery which in turn may increase police legitimacy. This possibility is salient to hot spots policing as Kochel and Weisburd (2018) note that increased community perceptions of police legitimacy and trust can cultivate collective efficacy, consistent with the cooperation hypothesis. Furthermore, police service-delivery partnership patrols may also provide police an opportunity to communicate directly with drug-involved persons (suspects and victims). As drug dealers and drug purchasers (users) often frequent the same geographic space (Eck \& Weisburd, 2015), police may be well-positioned to increase their presence and communicate with the most relevant persons. This could also enable tactics such as pedestrian stops, for example, to be employed as this has been shown to inhibit drug dealers from remaining in a drug hot spot even when no formal police action is taken (Haberman, 2016).

Opioid overdose hot spots can also have direct implications for agencies using nasal naloxone - an opioid antagonist that can be administered intravenously, intramuscularly, subcutaneously, or intranasally and displaces and blocks opioid agonists from receptor sites, effectively reversing an opioid overdose. For more than 40 years naloxone has been used by emergency medical personnel as standard procedures to revers an opioid-related overdose (Clarke et al., 2005) with few serious adverse events following administration (Wermeling, 2015). In an effort to combat this growing epidemic, there have been numerous initiatives taken to increase access to naloxone to police (Davis et al., 2014). While research is limited, findings suggest that police are accepting of these policies and are able to effectively administer naloxone (Ray et al., 2015; Fisher at al., 2016) with some evidence suggesting that these policies are associated with reductions in opioid overdose deaths (Rando et al., 2015). All officers are equipped with naloxone in Indianapolis, however many agencies have yet to embrace this strategy - likely due to cost that 
range from \$22-\$60 per kit (Bureau of Justice Assistance, 2018). Results from the present study suggest naloxone distribution by police can be more targeted by identifying opioid hot spots and equipping officers assigned to these locations. Despite growing access to naloxone by first responders and lay persons, EMS remains the primary source of out of hospital naloxone administration (Davis et al., 2014). Therefore, perhaps equally important are Good Samaritan laws which protect individuals who report an overdose and often complement efforts to distribute naloxone. Bystanders who witness a drug overdose often are reluctant to call 911 for fear of police involvement, but with legal safeguards in place police may be enabled to more readily serve as effective drug overdose first responders (Clark et al., 2014). Though this discussion focuses on implications for police intervention, the spatial concentration of opioid overdoses can also be informative for service allocation from social and clinical organizations. Indeed, overdose hot spots can be interpreted as focus areas for service demand, perhaps in the form of mobile treatment programs.

Lastly, in this study we considered the problem of estimating crime concentration when the volume of incidents is low. While the standard empirical measure of crime concentration is biased towards over-estimating crime concentration (Bernasco \& Steenbeek 2017), we showed that recent attempts to correct the estimate are biased towards under-estimating crime concentration. In this work we proposed using leading indicator hotspots with high volume of events as a proxy. Future research should focus on deriving unbiased estimators for crime concentration that will extend to the situation where no leading indicator incidents are available. Relatedly, we urge scholars to extend spatial concentration studies beyond crime to encompass a broader, and equally serious, set of societal challenges. Opioid overdose deaths is just one of many public health issues that could benefit from data-driven strategies. Specific to opioids, future 
research should seek to replicate the spatial concentrations observed in the present study to develop an evidence-base that can be used to assess the generalizability of Weisburd's (2015) law of crime concentration to other public health issues. Considerable work is also needed to better explain the environmental and offending nature of opioid drug use, why such incidents highly concentrate, and identify the co-occurring symptoms that are likely present in these micro-places (White \& Weisburd, 2017). Methods such as systematic social observation, either in person or via video technology (Olaghere and Lum, 2008), and agent-based computer modeling (Groff, Johnson \& Thornton, 2018) may be fruitful in this endeavor. 


\section{References}

Algren, D. A., Monteilh, C. P., Punja, M., Schier, J. G., Belson, M., Hepler, B. R., .. . Paulozzi, L. J. (2013). Fentanyl-associated fatalities among illicit drug users in Wayne County, Michigan (July 2005-May 2006). Journal of Medical Toxicology, 9(1), 106-115.

Andresen, M. A., Curman, A. S., \& Linning, S. J. (2017). The trajectories of crime at places: Understanding the patterns of disaggregated crime types. Journal of Quantitative Criminology, 33(3), 427-449.

Andresen, M. A., \& Malleson, N. (2011) Testing the stability of crime patterns: implications for theory and policy. Journal of Research in Crime and Delinquency, 48(1), 58-82.

Avella, J., Katz, M., \& Lehrer, M. (2007). Assessing free and total morphine following heroin overdose when complicated by the presence of toxic amitriptyline levels. Journal of Analytical Toxicology, 31(8), 540-542.

Baudains, P., Braithwaite, A., \& Johnson, S. D. (2013). Target choice during extreme events: A discrete spatial choice model of the 2011 London riots. Criminology, 51(2), 251-285.

Bernasco, W., \& Steenbeek, W. (2017). More places than crimes: Implications for evaluating the law of crime concentration at place. Journal of Quantitative Criminology, 33(3), 451-467.

Braga, A. A., \& Clarke, R. V. (2014). Explaining high-risk concentrations of crime in the city: Social disorganization, crime opportunities, and important next steps. Journal of Research in Crime and Delinquency. 51(4), 480-498.

Braga, A. A., Papachristos, A. V., Hureau, D. M. (2010). The concentration and stability of gun violence at micro places in Boston, 1980-2008. Journal of Quantitative Criminology, 26(1), 33-53.

Braga, A. A., Papachristos, A. V., Hureau, D. M. (2014). The effects of hot spots policing on crime: An updated systematic review and meta-analysis. Justice Quarterly, 31(4), 633-663.

Braga, A. A., \& Weisburd, D. (2006). Problem-oriented policing: The disconnect between principles and practice. In D. Weisburd \& A. A. Braga (Eds.), Police Innovation: Contrasting Perspectives. Cambridge University Press: Cambridge, U.K.

Brantingham, P. J., \& Brantingham, P L. (1981). Environmental Criminology. Beverly Hills, CA: Sage. 
Brantingham, P. J., \& Brantingham, P. L. (1993). Environment, routine, and situation: Toward a pattern theory of crime. In R. V. Clarke \& M. Felson (Eds.), Routine Activity and Rational Choice. Transaction: New Brunswick, NJ.

Brantingham, P. J. (2016). Crime diversity. Criminology, 54(4), 553-586.

Brantingham, P. J., \& Tita, G. (2008). Offender mobility and crime pattern formation from first principles. In L. Liu \& J. Eck (Eds.) Artificial crime analysis systems: Using computer simulations and geographic information systems (pp. 193-208). New York, NY: Information Science Reference.

Carroll, J. J., Marshall, B. D. L., Rich, J. D., \& Green, T. C. (2017). Exposure to fentanylcontaminated heroin and overdose risk among illicit opioid users in Rhode Island: A mixed methods study. International Journal of Drug Policy, 46, 136-145.

Casteel, K. (2018). There is More than One Opioid Crisis. FiveThirtyEight. Retrieved from https://fivethirtyeight.com/features/there-is-more-than-one-opioid-crisis/

Centers for Disease Control and Prevention (CDC). (2011). Vital signs: Overdoses of prescription opioid pain relievers - United States, 1999-2008. MMWR. Morbidity and Mortality Weekly Report, 60(43), 1487-1492.

Centers for Disease Control and Prevention (CDC). (2016). Wide-ranging online data for epidemiologic research (WONDER). CDC: Atlanta, GA. National Center for Health Statistics; 2015. Retrieved from: http://wonder.cdc.gov.

Chamberlain, J. M., \& Klein, B. L. (1994). A comprehensive review of naloxone for the emergency physician. The American Journal of Emergency Medicine, 12(6), 650-660.

Chiu, Y., Leclerc, B., \& Townsley, M. (2011). Crime script analysis of drug manufacturing in clandestine laboratories: Implications for prevention. British Journal of Criminology, 51(2), 355-374.

Clark, A. K., Wilder, C. M., \& Winstanley, E. L. (2014). A systematic review of community opioid overdose prevention and naloxone distribution programs. Journal of Addiction Medicine, 8(3), 153-163.

Clarke, S. F. J., Dargan, P. I., \& Jones, A. L. (2005). Naloxone in opioid poisoning: walking the tightrope. Emergency Medicine Journal, 22(9), 612-616. 
Clarke, R. V., \& Cornish, D. B. (1985). Modeling offender's decisions: A framework for research and policy. In M. Tonry \& N. Morris (Eds), Crime and Justice: A Review of Research, 6. University of Chicago Press: Chicago, IL.

Cohen, J., Gorr, W. L., \& Olligschlaeger, A. M. (2007). Leading indicators and spatial interactions: A crime-forecasting model for proactive police deployment. Geographical Analysis, 39(1), 105-127.

Coben, J. H., Davis, S. M., Furbee, P. M., Sikora, R. D., Tillotson, R. D., \& Bossarte, R. M. (2010). Hospitalizations for poisoning by prescription opioids, sedatives, and tranquilizers. American Journal of Preventive Medicine, 38(5), 517-524.

Cohen, L., \& Felson, M. (1979). Social change and crime rate trends: A routine activity approach. American Sociological Review, 44(4), 588-608.

Cornish, D. B., \& Clarke, R. V. (2002). Analyzing Organized Crimes. In A. Piquero \& S. Tibbetts (Eds) Rational Choice and Criminal Behavior, pp. 41-64. London, UK: Routledge.

Compton, W. M., Conway, K. P., Stinson, F. S., Colliver, J. D., \& Grant, B. F. (2005). Prevalence, correlates, and comorbidity of DSM-IV antisocial personality syndromes and alcohol and specific drug use disorders in the United States: Results from the national epidemiologic survey on alcohol and related conditions. The Journal of Clinical Psychiatry, 66(6), 677-685.

Davis, C. S., Ruiz, S., Glynn, P., Picariello, G., \& Walley, A. Y. (2014). Expanded Access to Naloxone Among Firefighters, Police Officers, and Emergency Medical Technicians in Massachusetts. American Journal of Public Health, 104(8), e7-e9.

Davis, C. S., Southwell, J. K., Niehaus, V. R., Walley, A. Y., \& Dailey, M. W. (2014). Emergency medical services naloxone access: a national systematic legal review. Academic Emergency Medicine, 21(10), 1173-1177.

Eck, J., \& Weisburd, D. (2015). Crime places in crime theory. Crime and Place: Crime Prevention Studies, 4, 1-33.

Fernandez, W., Hackman, H., McKeown, L., Anderson, T., \& Hume, B. (2006). Trends in opioidrelated fatal overdoses in Massachusetts, 1990-2003. Journal of Substance Abuse Treatment, 31(2), 151-156.

Fisher, R., O'Donnell, D., Ray, B., \& Rusyniak, D. (2016). Police Officers Can Safely and Effectively Administer Intranasal Naloxone. Prehospital Emergency Care, 1-6. 
Garnier, S., Caplan, J. M., \& Kennedy, L. W. (2018). Predicting dynamical crime distribution from environmental and social influences. Frontiers in Applied Mathematics and Statistics, 4(13). doi: 10.3389/fams.2018.00013

Groff, E. R., Johnson, S. D., \& Thornton, A. (2018). State of the art in agent-based modeling of urban crime: An overview. Journal of Quantitative Criminology. Online First. https://doi.org/10.1007/s10940-018-9376-y

Guerette, R. T., \& Bowers, K. J. (2009). Assessing the extent of crime displacement and diffusion of benefits: A review of situational crime prevention evaluations. Criminology, 47(4), 13311368.

Guy, J. G., Zhang, K., Bohm, M. K., Losby, J., Lewis, B., Young, R., . . Dowell, D. (2017). Vital Signs: Changes in Opioid Prescribing in the United States, 2006-2015. MMWR. Morbidity and Mortality Weekly Report, 66(26), 697-704.

Haberman, C. P. (2016). A view inside the "black box" of hot spots policing from a sample of police commanders. Police Quarterly, 19(4), 488-517.

Haberman, C. P. (2017). Overlapping hot spots? Examination of the spatial heterogeneity of hot spots of different crime types. Criminology \& Public Policy, 16(2), 633-660.

Harruff, R., Couper, F., \& Banta-Green, C. (2015). Tracking the opioid drug overdose epidemic in King County, Washington using an improved methodology for certifying heroin-related deaths. Academy Forensic Pathology, 5(1), 499-506.

Hibdon, J., \& Groff, E. R. (2014). What you find depends on where you look: Using emergency medical services call data to target illicit drug use hot spots. Journal of Contemporary Criminal Justice, 30(2), 169-185.

Hibdon, J., Telep, C. W., \& Groff, E. R. (2017). The concentration and stability of drug activity in Seattle, Washington using police and emergency medical services data. Journal of Quantitative Criminology 33(3), 497-517.

Hipp, J. R., \& Kim, Y. (2017). Measuring crime concentration across cities of varying sizes: Complications based on the spatial and temporal scale employed. Journal of Quantitative Criminology, 33(3), 595-632.

Hsu, K., \& Miller, J. (2017). Assessing the situational predictors of drug markets across street segments and intersections. Journal of Research in Crime and Delinquency, 54(6), 902-929. 
Johnson, S. D. (2014). How do offenders choose where to offend? Perspectives from animal foraging. Legal and Criminological Psychology, 19, 193-210.

Johnson, S. D., \& Bowers, K. J. (2004). The stability of space-time clusters of burglary. British Journal of Criminology, 44(1), 55-65.

Johnson, S. D., \& Summers, L. (2015). Testing ecological theories of offender spatial decision making using a discrete choice model. Crime \& Delinquency, 61(3), 454-480.

Johnson, S. D., Summers, L., \& Pease, K. (2009). Offender as forager? A direct test of the boost account of victimization. Journal of Quantitative Criminology, 25(2), 181-200.

Jones, C. M., Einstein, E. B., \& Compton, W. M. (2018). Changes in synthetic opioid involvement in drug overdose deaths in the United States, 2010-2016. Journal of the American Medical Association, 319(17), 1819-1821.

Kochel, T. R., \& Weisburd, D. (2018). The impact of hot spots policing on collective efficacy: Findings from a randomized field trial. Justice Quarterly. Online First. DOI: 10.1080/07418825.2018.1465579

Lawton, B. A., Taylor, R. B., \& Luongo, A. J. (2005). Police officers on drug corners in Philadelphia, drug crime, and violent crime: Intended, diffusion, and displacement impacts. Justice Quarterly, 22(4), 427-451.

Lum, C. (2008). The geography of drug activity and violence: Analyzing spatial relationships of non-homogenous crime event types. Substance Use \& Misuse, 43(2), 179-201.

Madensen, T. D., \& Eck, J. (2013). Crime Places and Place Management. In F. Cullen \& P. Wilcox (Eds.), The Oxford Handbook of Criminological Theory. New York: Oxford University Press.

Mair, C., Gruenewald, P. J., Ponicki, W. R., \& Remer, L. (2013). Varying impacts of alcohol outlet densities on violent assaults: Explaining differences across neighborhoods. Journal of Studies on Alcohol and Drugs. 74(1), 50-58.

Manchikanti L, Helm, S., Fellows, B., Janata, J. W., Pampati, V., Grider, J. S., \& Boswell, M. V.. (2012). Opioid epidemic in the United States. Pain physician, 15, 2150-1149.

Mohler, G. O., Carter, J. G., \& Raje, R. (2018). Improving social harm indices with a modulated Hawkes process. International Journal of Forecasting, 34(3), 431-439. 
Mohler, G. O., Short, M. B., \& Brantingham, P. J. (2017). The concentration dynamics tradeoff in crime hot spotting. In. D. Weisburd \& J. Eck (Eds.), Unraveling the Crime-Place Connection, 22, 19-40. Taylor and Francis: Oxford, U.K.

Mohler, G. (2014). Marked point process hotspot maps for homicide and gun crime prediction in Chicago. International Journal of Forecasting, 30(3), 491-497.

National Academies of Sciences, Engineering, and Medicine. (2018). Proactive Policing: Effects on Crime and Communities. Washington, DC: The National Academies Press. doi:https://doi.org/10.17226/24928.

National Center for Injury Prevention and Control. (2016) Opioid Overdose: Synthetic Opioid Data. Centers for Disease Control and Prevention. Retrieved from https://www.cdc.gov/drugoverdose/data/fentanyl.html.

Nelson, L. S., Juurlink, D. N., \& Perrone, J. (2015). Addressing the opioid epidemic. Journal of the American Medical Association, 314(14), 1453-1454.

Olaghere, A., \& Lum, C. (2018). Classifying “micro” routine activities of street-level drug transactions. Journal of Research in Crime and Delinquency. Online First. DOI: $10.1177 / 0022427818760103$

Ossiander, E. M. (2014). Using textual cause-of-death data to study drug poisoning deaths. American Journal of Epidemiology, 179(7), 884-894.

Piza, E. L., Feng, S., Kennedy, L., \& Caplan, J. (2017). Place-based correlates of motor vehicle theft and recovery: Measuring spatial influence across neighborhood context. Urban Studies, 54(13), 2998-3021.

Phalen, P., Ray, B., Watson, D., Huynh, P., \& Greene, M. (2018). Fentanyl related overdose in Indianapolis: Estimating trends using multilevel Bayesian model. Addictive Behaviors. Online First. https://doi.org/10.1016/j.addbeh.2018.03.010

Rando, J., Broering, D., Olson, J. E., Marco, C., \& Evans, S. B. (2015). Intranasal naloxone administration by police first responders is associated with decreased opioid overdose deaths. American Journal of Emergency Medicine, 33(9), 1201-1204.

Ratcliffe, J. H. (2004). Geocoding rate and a first estimate of a minimum acceptable hit rate. International Journal of Geographical Information Science, 18(1), 61-72.

Ratcliffe, J. H. (2015). Towards an index for harm-focused policing. Policing: A Journal of Policy and Practice, 9(2), 164-183. 
Ratcliffe, J. H., Taniguchi, T., Groff, E. R., \& Wood, J. D. (2011). The Philadelphia foot patrol experiment: A randomized controlled trial of police patrol effectiveness in violent crime hot spots. Criminology, 49(3), 795-832.

Ray, B., Lowder, E. M., Kivisto, A. J., Phalen, P., \& Gil, H. (2018). EMS naloxone administration as non-fatal opioid overdose surveillance: Six-year outcomes in Marion County, Indiana. Working Paper. Indiana University.

Ray, B., O’Donnell, D., \& Kahre, K. (2015). Police officer attitudes towards intranasal naloxone training. Drug and Alcohol Dependence, 146, 107-110.

Rengert, G. F., \& Wasilchick, J. (1989). Space, Time, and Crime: Ethnographic Insights into Residential Burglary. U.S. Department of Justice: Washington, DC.

Reuland, M., Draper, L., \& Norton, B. (2010). Improving Responses to People with Mental Illnesses: Tailoring Law Enforcement Initiatives to Individual Jurisdictions. Bureau of Justice Assistance: Washington, DC.

Sampson, R. J., \& Groves, W. B. (1989). Community structure and crime: Testing socialdisorganization theory. American Journal of Sociology, 94(4), 774-802.

Sampson, R. J., Raudenbush, S. W. (1999). Systematic social observation of public spaces: A new look at disorder in urban neighborhoods. American Journal of Sociology, 105(3), 603-651.

Sampson, R. J., Raudenbush, S. W., \& Earls, F. (1997). Neighborhoods and violent crime: A multilevel study of collective efficacy. Science, 277(5328), 918-924.

Schnell, C., Braga, A. A., \& Piza, E. L. (2017). The influence of community areas, neighborhood clusters, and street segments on the spatial variability of violent crime in Chicago. Journal of Quantitative Criminology, 33(3), 469-496.

Shaw, C. R., \& McKay, H. D. (1942). Juvenile Delinquency and Urban Areas: A Study of Delinquency in Relation to Differential Characteristics of Local Communities in American Cities. University of Chicago Press: Chicago, IL.

Sherman, L. W., Gartin, P. R., \& Buerger, M. E. (1989). Hot spots of predatory crime: Routine activities and the criminology of place. Criminology, 27(1), 27-56.

Sherman, L. W., Neyroud, P. W., \& Neyroud, E. (2016). The Cambridge crime harm index: measuring total harm from crime based on sentencing guidelines. Policing: A Journal of Policy and Practice, 10(3), 171-183. 
Skogan, W. G. (1990). Disorder and Decline: Crime and the Spiral of Decay in American Neighborhoods. Free Press: New York.

State of Indiana. (2018). 2016 Opioid Prescriptions Per 100 Residents. Indiana by the Numbers. Retrieved from https://www.in.gov/recovery/1054.htm.

Substance Abuse and Mental Health Services Administration and Center for Behavioral Health Statistics and Quality. (2017). Treatment Episode Data Set -- Admissions (TEDS-A). Retrieved from http://wwwdasis.samhsa.gov/dasis2/teds.htm

Taylor, R. B. (2015). Community Criminology: Fundamentals of Spatial and Temporal Scaling, Ecological Indicators, and Selectivity Bias. New York University Press: New York.

Warner, M., Chen, L. H., Makuc, D. M., Anderson, R. N., \& Miniño, A. M, (2011). Drug poisoning deaths in the United States, 1980-2008. National Center for Health Statistics: Hyattsville, MD.

Warner, M., Paulozzi, L. J., Nolte, K. B., Davis, G. G., \& Nelson, L. S. (2013). State variation in certifying manner of death and drugs involved in drug intoxication deaths. Academic Forensic Pathology, 3(2), 231-237.

Weisburd, D. (2015). The law of crime concentration and the criminology of place. Criminology, 53(1), 133-157.

Weisburd, D. (2018). Hot spots of crime and place-based prevention. Criminology \& Public Policy, 17(1), 5-25.

Weisburd, D., Bushway, S., Lum, C., \& Yang, S. (2004). Trajectories of crime at places: A longitudinal study of street segments in the city of Seattle. Criminology, 42(2), 283-322.

Weisburd, D., \& Green, L. (1995). Policing drug hot spots: The Jersey City drug market analysis experiment. Justice Quarterly, 12(4), 711-735.

Weisburd D., Groff, E. R., \& Yang, S. (2012a) The Criminology of Place: Street Segments and our Understanding of the Crime Problem. Oxford University Press: New York.

Weisburd, D., Groff, R. E., \& Yang, S. (2014). Understanding and controlling hot spots of crime: The importance of formal and informal social controls. Prevention Science, 15(1), 31-43.

Weisburd, D., Lawton, B., \& Ready, J. (2012b). Staking out the next generation of studies of the criminology of place. In The Future of Criminology. Oxford, U.K.: Oxford University Press.

Weisburd, D., Maher, L., Sherman, L., Buerger, M., Cohn, E., \& Petrisino, A. (1993). Contrasting crime general and crime specific theory: The case of hot spots of crime. In F. Adler \& W. S. 
Laufer (Eds.), New Directions in Criminological Theory: Advances in Criminological Theory. Transaction: New Brunswick, NJ.

Weisburd, D., \& Mazerolle, L. (2000). Crime and disorder in drug hot spots: Implications for theory and practice in policing. Police Quarterly, 3(3), 331-349.

Weisburd, D., Shay, M., Amram, S., \& Zamir, R. (2017). The relationship between social disorganization and crime at street segments: Findings from Tel Aviv Jaffa using census data. In D. Weisburd \& J. Eck (Eds.), Unravelling the Crime Place Connection. Taylor and Francis: Oxford, U.K.

Weisburd, D., \& Telep, C. (2014). Hot spots policing: What we know and what we need to know. Journal of Contemporary Criminal Justice, 30(2), 200-220.

Weisburd, D., Wyckoff, L. A., Ready, J., Eck, J. E., Hinkle, J. C., \& Gajewski, F. (2006). Does crime just move around the corner? A controlled study of spatial displacement and diffusion of crime control benefits. Criminology, 44(3), 549-592.

Wermeling, D. P. (2010). Opioid Harm Reduction Strategies: Focus on Expanded Access to Intranasal Naloxone. Pharmacotherapy, 30(7), 627-631.

Wheeler, A. P. (2017). The effect of 311 calls for service on crime in D.C. at microplaces. Crime and Delinquency. Online First. https://doi.org/10.1177/0011128717714974

Wheeler, A. P., Worden, R. E., \& McLean, S. J. (2016). Replicating group-based trajectory models of crime at micro-places in Albany, NY. Journal of Quantitative Criminology, 32(4), 589612.

White, C. \& Weisburd, D. (2017). A co-responder model for policing mental health problems at crime hot spots: Findings from a pilot Project. Policing: A Journal of Policy and Practice. Online First. DOI: 10.1093/police/pax010

Wilson, J. Q., \& Kelling, G. L. (1982). Broken windows: The police and neighborhood safety. The Atlantic Magazine. March, 29-38.

Wilson, P. R., Caplan, R. A., Connis, R. T., Gilbert, H. C., Grigsby, E. J., Haddox, J. D., . . Simon, D. L. (1997). Practice guidelines for chronic pain management: a report by the American Society of Anesthesiologists Task Force on Pain Management, Chronic Pain Section. Anesthesiology, 86(4), 995-1004. 
Wortley, R., \& Mazerolle, L. (2008). Environmental criminology and crime analysis: Situating the theory, analytic approach and application. In R. Wortley \& L. Mazerolle (Eds.), Environmental Criminology and Crime Analysis. Willan: Portland, OR.

Wright, R., \& Decker, S. (1997). Armed Robbers in Action: Stickups and Street Culture. Northeastern University Press: Boston, MA.

Wysowski, D. K. (2007). Surveillance of prescription drug-related mortality using death certificate data. Drug Safety, 30(6), 533-540. 
Tables and Figures

Table 1: Concentration by Incident Type, Cell Size, and Percent of Area Flagged

\begin{tabular}{|c|c|c|c|c|}
\hline Incident Type & $\begin{array}{c}\text { Cell Size } \\
\text { (Sq. Meters) }\end{array}$ & $\begin{array}{c}\text { Percent Area } \\
\text { Flagged }\end{array}$ & $\begin{array}{c}\text { Percent Incidents } \\
\text { Captured }\end{array}$ & $\mathbf{N}$ \\
\hline Drug Overdose & 500 & $1.0 \%$ & $21.5 \%$ & 16629 \\
\hline Any Opioid Death & 500 & $1.0 \%$ & $17.0 \%$ & 966 \\
\hline Any Illicit Opioid Death & 500 & $1.0 \%$ & $20.5 \%$ & 654 \\
\hline Any Prescription Opioid Death & 500 & $1.0 \%$ & $22.1 \%$ & 458 \\
\hline Motor Vehicle Theft & 500 & $1.0 \%$ & $12.9 \%$ & 53235 \\
\hline Burglary & 500 & $1.0 \%$ & $10.6 \%$ & 63489 \\
\hline Assault & 500 & $1.0 \%$ & $14.6 \%$ & 96333 \\
\hline Robbery & 500 & $1.0 \%$ & $17.4 \%$ & 18882 \\
\hline Drug Overdose & 1000 & $1.0 \%$ & $16.6 \%$ & 16629 \\
\hline Any Opioid Death & 1000 & $1.0 \%$ & $10.9 \%$ & 966 \\
\hline Any Illicit Opioid Death & 1000 & $1.0 \%$ & $11.9 \%$ & 654 \\
\hline Any Prescription Opioid Death & 1000 & $1.0 \%$ & $13.5 \%$ & 458 \\
\hline Motor Vehicle Theft & 1000 & $1.0 \%$ & $9.1 \%$ & 53235 \\
\hline Burglary & 1000 & $1.0 \%$ & $8.0 \%$ & 63489 \\
\hline Assault & 1000 & $1.0 \%$ & $11.4 \%$ & 96333 \\
\hline Robbery & 1000 & $1.0 \%$ & $12.6 \%$ & 18882 \\
\hline Drug Overdose & 500 & $2.5 \%$ & $35.1 \%$ & 16629 \\
\hline Any Opioid Death & 500 & $2.5 \%$ & $31.8 \%$ & 966 \\
\hline Any Illicit Opioid Death & 500 & $2.5 \%$ & $39.8 \%$ & 654 \\
\hline Any Prescription Opioid Death & 500 & $2.5 \%$ & $41.7 \%$ & 458 \\
\hline Motor Vehicle Theft & 500 & $2.5 \%$ & $22.3 \%$ & 53235 \\
\hline Burglary & 500 & $2.5 \%$ & $20.9 \%$ & 63489 \\
\hline Assault & 500 & $2.5 \%$ & $26.1 \%$ & 96333 \\
\hline Robbery & 500 & $2.5 \%$ & $32.2 \%$ & 18882 \\
\hline Drug Overdose & 1000 & $2.5 \%$ & $28.8 \%$ & 16629 \\
\hline Any Opioid Death & 1000 & $2.5 \%$ & $22.5 \%$ & 966 \\
\hline Any Illicit Opioid Death & 1000 & $2.5 \%$ & $23.5 \%$ & 654 \\
\hline Any Prescription Opioid Death & 1000 & $2.5 \%$ & $27.1 \%$ & 458 \\
\hline Motor Vehicle Theft & 1000 & $2.5 \%$ & $16.6 \%$ & 53235 \\
\hline Burglary & 1000 & $2.5 \%$ & $16.5 \%$ & 63489 \\
\hline Assault & 1000 & $2.5 \%$ & $21.3 \%$ & 96333 \\
\hline Robbery & 1000 & $2.5 \%$ & $24.2 \%$ & 18882 \\
\hline Drug Overdose & 500 & $5.0 \%$ & $49.0 \%$ & 16629 \\
\hline Any Opioid Death & 500 & $5.0 \%$ & $53.5 \%$ & 966 \\
\hline
\end{tabular}




\begin{tabular}{lcccc} 
Any Illicit Opioid Death & 500 & $5.0 \%$ & $57.5 \%$ & 654 \\
Any Prescription Opioid Death & 500 & $5.0 \%$ & $64.8 \%$ & 458 \\
Motor Vehicle Theft & 500 & $5.0 \%$ & $33.7 \%$ & 53235 \\
Burglary & 500 & $5.0 \%$ & $34.1 \%$ & 63489 \\
Assault & 500 & $5.0 \%$ & $40.0 \%$ & 96333 \\
Robbery & 500 & $5.0 \%$ & $48.5 \%$ & 18882 \\
& & & \\
Drug Overdose & 1000 & $5.0 \%$ & $42.0 \%$ & 16629 \\
Any Opioid Death & 1000 & $5.0 \%$ & $35.7 \%$ & 966 \\
Any Illicit Opioid Death & 1000 & $5.0 \%$ & $38.2 \%$ & 654 \\
Any Prescription Opioid Death & 1000 & $5.0 \%$ & $41.9 \%$ & 458 \\
Motor Vehicle Theft & 1000 & $5.0 \%$ & $26.2 \%$ & 53235 \\
Burglary & 1000 & $5.0 \%$ & $27.7 \%$ & 63489 \\
Assault & 1000 & $5.0 \%$ & $33.2 \%$ & 96333 \\
Robbery & 1000 & $5.0 \%$ & $37.9 \%$ & 18882 \\
\hline
\end{tabular}

Table 2: Corrected Gini Coefficients by Incident Type and Cell Size

\begin{tabular}{lcccc}
\hline \multicolumn{1}{c}{ Incident Type } & $\begin{array}{c}\text { Cell Size } \\
\text { (Sq. Meters) }\end{array}$ & Percent Area Flagged & Gini Coefficient & N \\
\hline Drug Overdose & 500 & $1.0 \%$ & 0.823 & 16629 \\
Any Opioid Death & 500 & $1.0 \%$ & 0.480 & 966 \\
Any Illicit Opioid Death & 500 & $1.0 \%$ & 0.404 & 654 \\
Any Prescription Opioid Death & 500 & $1.0 \%$ & 0.313 & 458 \\
Motor Vehicle Theft & 500 & $1.0 \%$ & 0.692 & 53235 \\
Burglary & 500 & $1.0 \%$ & 0.716 & 63489 \\
Assault & 500 & $1.0 \%$ & 0.766 & 96333 \\
Robbery & 500 & $1.0 \%$ & 0.832 & 18882 \\
& & & & \\
Drug Overdose & 1000 & $1.0 \%$ & 0.770 & 16629 \\
Any Opioid Death & 1000 & $1.0 \%$ & 0.731 & 966 \\
Any Illicit Opioid Death & 1000 & $1.0 \%$ & 0.668 & 654 \\
Any Prescription Opioid Death & 1000 & $1.0 \%$ & 0.579 & 458 \\
Motor Vehicle Theft & 1000 & $1.0 \%$ & 0.612 & 53235 \\
Burglary & 1000 & $1.0 \%$ & 0.653 & 63489 \\
Assault & 1000 & $1.0 \%$ & 0.707 & 96333 \\
Robbery & 1000 & $1.0 \%$ & 0.767 & 18882 \\
Drug Overdose & & & & 16629 \\
Any Opioid Death & 500 & $2.5 \%$ & 0.823 & 966 \\
Any Illicit Opioid Death & 500 & $2.5 \%$ & 0.480 & 654 \\
Any Prescription Opioid Death & 500 & $2.5 \%$ & 0.404 & 458 \\
Motor Vehicle Theft & 500 & $2.5 \%$ & 0.692 & 53235
\end{tabular}




\begin{tabular}{lcccc} 
Burglary & 500 & $2.5 \%$ & 0.716 & 63489 \\
Assault & 500 & $2.5 \%$ & 0.766 & 96333 \\
Robbery & 500 & $2.5 \%$ & 0.832 & 18882 \\
& & & & \\
Drug Overdose & 1000 & $2.5 \%$ & 0.770 & 16629 \\
Any Opioid Death & 1000 & $2.5 \%$ & 0.731 & 966 \\
Any Illicit Opioid Death & 1000 & $2.5 \%$ & 0.668 & 654 \\
Any Prescription Opioid Death & 1000 & $2.5 \%$ & 0.579 & 458 \\
Motor Vehicle Theft & 1000 & $2.5 \%$ & 0.612 & 53235 \\
Burglary & 1000 & $2.5 \%$ & 0.653 & 63489 \\
Assault & 1000 & $2.5 \%$ & 0.707 & 96333 \\
Robbery & 1000 & $2.5 \%$ & 0.767 & 18882 \\
& & & & \\
Drug Overdose & 500 & $5.0 \%$ & 0.823 & 16629 \\
Any Opioid Death & 500 & $5.0 \%$ & 0.480 & 966 \\
Any Illicit Opioid Death & 500 & $5.0 \%$ & 0.404 & 654 \\
Any Prescription Opioid Death & 500 & $5.0 \%$ & 0.313 & 458 \\
Motor Vehicle Theft & 500 & $5.0 \%$ & 0.692 & 53235 \\
Burglary & 500 & $5.0 \%$ & 0.716 & 63489 \\
Assault & 500 & $5.0 \%$ & 0.766 & 96333 \\
Robbery & 500 & $5.0 \%$ & 0.832 & 18882 \\
Drug Overdose & & & & 0.770 \\
Any Opioid Death & 1000 & $5.0 \%$ & 0.731 & 96629 \\
Any Illicit Opioid Death & 1000 & $5.0 \%$ & 0.668 & 654 \\
Any Prescription Opioid Death & 1000 & $5.0 \%$ & 0.579 & 458 \\
Motor Vehicle Theft & 1000 & $5.0 \%$ & 0.612 & 53235 \\
Burglary & 1000 & $5.0 \%$ & 0.653 & 63489 \\
Assault & 1000 & $5.0 \%$ & 0.767 & 96333 \\
Robbery & 1000 & $5.0 \%$ & & 18882 \\
\hline
\end{tabular}


Table 3: Opioid Death Concentration in Leading Indicator Hot Spots

\begin{tabular}{lccccc}
\hline \multicolumn{1}{c}{ Incident Type } & $\begin{array}{c}\text { Cell Size } \\
\text { (Sq. Meters) }\end{array}$ & $\begin{array}{c}\text { Percent Area } \\
\text { Flagged }\end{array}$ & $\begin{array}{c}\text { Percent Incidents } \\
\text { Captured }\end{array}$ & N & S.E. \\
\hline Drug Overdose & 500 & $2.5 \%$ & $35.1 \%$ & 16629 & 0.015 \\
Robbery & 500 & $2.5 \%$ & $32.2 \%$ & 18882 & 0.015 \\
Assault & 500 & $2.5 \%$ & $26.1 \%$ & 96333 & 0.014 \\
Motor Vehicle Theft & 500 & $2.5 \%$ & $22.3 \%$ & 53235 & 0.013 \\
Burglary & 500 & $2.5 \%$ & $20.9 \%$ & 63489 & 0.013 \\
& & & & & \\
Drug Overdose & 500 & $5.0 \%$ & $49.0 \%$ & 16629 & 0.016 \\
Robbery & 500 & $5.0 \%$ & $48.5 \%$ & 18882 & 0.016 \\
Assault & 500 & $5.0 \%$ & $40.0 \%$ & 96333 & 0.016 \\
Burglary & 500 & $5.0 \%$ & $34.1 \%$ & 63489 & 0.015 \\
Motor Vehicle Theft & 500 & $5.0 \%$ & $33.7 \%$ & 53235 & 0.015 \\
\hline
\end{tabular}

Figure 1: Poisson-Gamma Simulation of Gini and Corrected Gini Coefficients

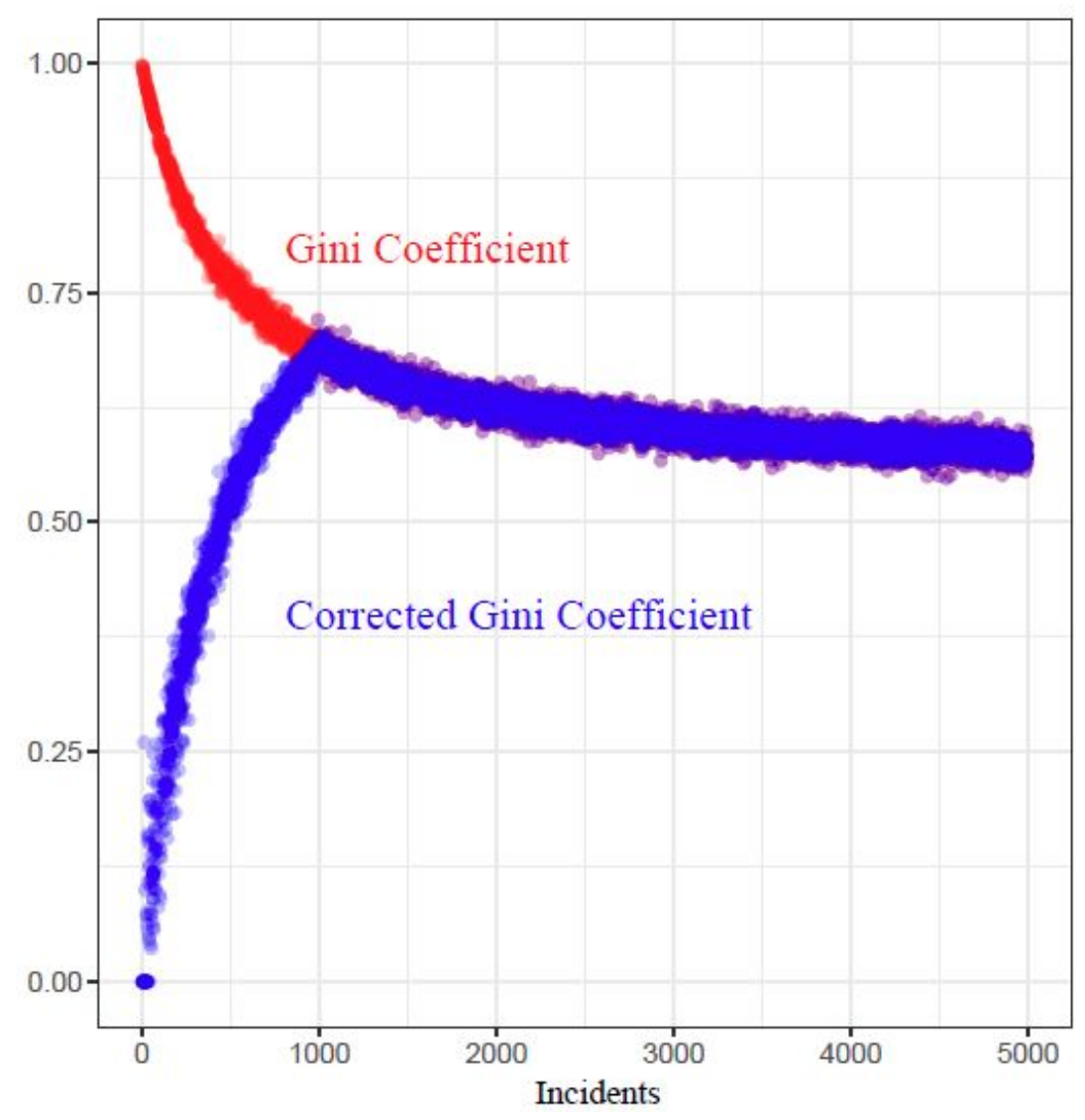


Figure 2: Density Maps of Opioid Death Concentrations within Other Incident Hot Spots

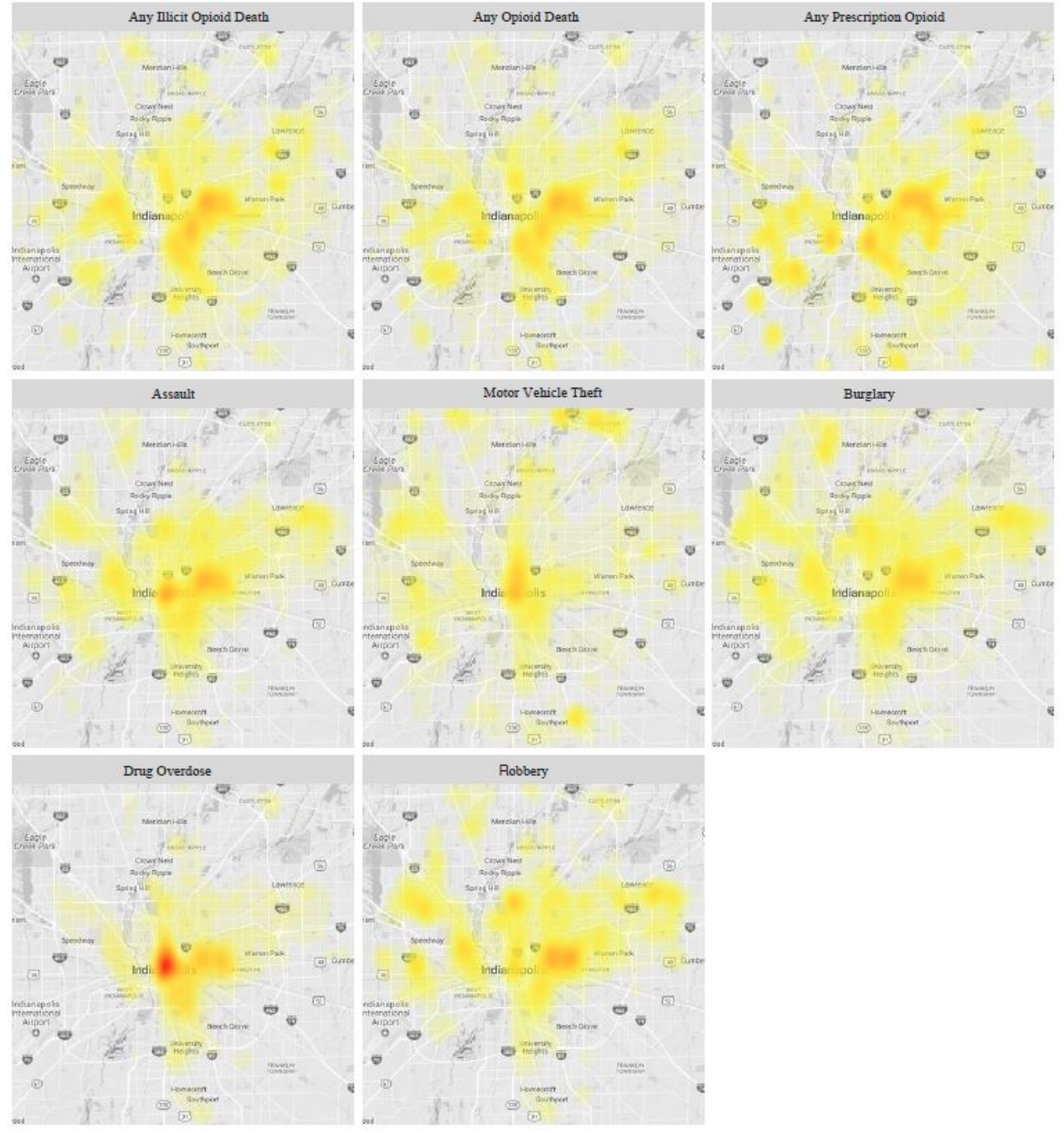

